\title{
The Effect of Competency Based Training (CBT) and Competency Certificate Type on The Ability of Graduates of The Work Training Center (BLK) of Wonogiri District at PT Top N Top
}

\author{
${ }^{1}$ Agung Susila *, ${ }^{2}$ Budi Santosa, ${ }^{3}$ Muhammad Sayuti \\ Email : 1 ridhoatin9@gmail.com*,2,budi.santosa@mgv.uad.ac.id,3 masyuti@uad.ac.id \\ * : coresponndensing author \\ 123 Universitas Ahmad Dahlan
}

Article history

Received May 27, 2021

Revised Nov 29, 2021

Accepted Nov 30, 2021

Keywords

effectiveness of competency based training

certificate of competency

work ability

BLK
The results showed that: (1) Based on the test, the results of the research proved that the Training Method (X1) proved to have a positive effect on the Work Ability of Training Graduates at UPTD BLK Wonogiri (Y); (2) Based on the test, it turns out that the results of the study prove that the Instructor / Trainer (X2) has no positive effect on the Work Ability of Training Graduates at UPTD BLK Wonogiri (Y); (3) Based on the test, it turns out that the research results prove that the Instructor / Trainer (X3) has a positive effect on the Work Ability of Training Graduates at UPTD BLK Wonogiri; (4) Based on the test, it turns out that the research results prove that the Method of Facilities and Infrastructure (X4) has a positive effect on the Work Ability of Training Graduates at UPTD BLK Wonogiri (Y); (5) Based on the test, it turns out that the research results prove that the certificate (X5) is proven to have a positive effect on the Work Ability of Training Graduates at UPTD BLK Wonogiri (Y); (6) Based on testing simultaneously (Test F), it turns out that the results of the research prove that all variables of Training Methods, Instructors / Trainers, Training Materials and Facilities and Infrastructure as well as certificates together or simultaneously prove to have a positive effect on the factor formation of the variables. Apparel Garment Program Training at UPTD BLK Wonogiri.

This is an open access article under the CC-BY-SA license.

\section{Introduction}

Human resources are an important factor in supporting the success of development. Human resource development activities will make a large contribution to improving the quality of human resources, which in turn will affect the increase in production and community welfare by increasing the income of individuals as economic actors. Improving the quality of human resources is carried out through channels including education and training as well as skills development in the workplace. Training is a pathway to improve the quality of human resources which emphasizes the 
formation and development of professionalism or competence.

Training is one type of learning process to acquire and improve skills outside the human resource development system that is in effect in a relatively short time with a method that prioritizes practice rather than theory (Sastradipoera, 2006). Each training process must be directed and continuous to achieve certain goals by achieving organizational goals (Hamalik, 2005). A training is said to be effective if the results of the training can achieve organizational goals, increase resource capabilities, satisfy consumers or can improve internal processes (Detty, 2009).

Job competence has motives and self-concepts that refer to attitudes and values, the following will explain the definitions of motives, attitudes, and values according to expert opinion. (Achmad, 2007) defines value: "values are beliefs held firmly by a person or group of people regarding actions and goals that should be used as a foundation or identity in the organization." The definition of competence according to (Palan, 2007) states that "competence is a characteristic that underlies behavior that describes motives, personal characteristics (characteristics), self-concept, values, knowledge and expertise brought by a person who has superior performance (superior performance) in the workplace. Zastrow (in Hikmat, 2001: 54) states that: "Competency is an ability to combine feelings, thoughts and all received behavior, so that it is able to adapt itself to various environments that are constantly changing. dynamic and able to meet needs and solve problems faced through the right steps. "

Based on the definition above, it is clearly explained that competence contains a set of knowledge, skills, or expertise and attitudes (personality) obtained from formal learning activities in educational institutions and non-formal institutions through work experience and training, because through these activities knowledge will be obtained. , attitude is formed and certain skills are in accordance with the field of work.

So, a competent person is a person who can make a real and meaningful contribution to the surrounding environment. Imaginative and innovative in approaching life's problems and intelligence (creative) in achieving their life goals. At the same time, people like this will always be responsible and responsive in their relationships with others (leadership). Instructors like this are organizational assets, who always try to improve themselves in the organization and will support the achievement of organizational productivity.rk.

Bacal (2004: 19) states that "instructors work best when they: a) have clear goals, b) believe they can achieve those goals, and c) know what they will receive when they achieve these goals. Then Ratminto (2008: 24) states "the competence of the giver officer must be determined appropriately based on the required knowledge, expertise, skills, attitudes, and behavior.

A good organization must have a vision and mission as well as a strategic plan to implement and serve as guidelines for every activity of an organization. By determining the mission and vision, it 
means that the organization sets the basic rules of the organization in carrying out activities. In addition, to achieve a common perception among the various levels as actors in organizational activities, it is necessary to have clarity about the vision that the organization must achieve. Basically, an increase in the ability of an instructor will give birth to a professional in his field.

The determinants of a person's work ability according to (Handoko, 2008) can be measured by "factors of formal education, training factors and work experience". (Mangkunegara, 2006) states "Quality improvement can be achieved through experience, education, training and development". Work competency (task competency) is very influential on the productivity of an organization that members must have and continue to develop in all situations that require the ability to carry out tasks as well as possible, in order to obtain production results in accordance with what is expected.

Wonogiri Regency in the last five years many investors have entered, including PT Nesia Pan Pacific, PT Top \& Top, PT Liebra Permana, PT Raja Busana. Most of the companies investing in Wonogiri are textile and textile product (TPT) companies. Opportunities for the need for labor in the garment sector are very high, this is due to the large demand for labor from new companies that have started operating in Wonogiri Regency, ncluding textile and garment companies PT Nesia Pan Pacific, PT Top \& Top, PT Liebra Permana, PT Raja Busana, and the wood processing company PT Naga Bhuana Aneka Piranti. textile and garment factory PT Nesia Pan Pacific in 2015 required around 12,000 workers. Meanwhile, PT Top \& Top requires 600 workers. This figure is much higher than the number of job seekers or job seekers (AK1 / Yellow Card) applicants. The number of yellow card applicants in the district is only 10,894 people (source of the 2017 Wonogiri Manpower Office).

The Wonogiri Vocational Training Center (BLK) as one of the government job training institutions under the Wonogiri Regency Manpower Office has a very important and strategic role in an effort to prepare a qualified and competent workforce in accordance with the requirements of the labor market qualifications. The role of BLK as a bridge to the needs of the job market requires a BLK curriculum program that is suitable for the job market. Many factors influence this so that a BLK is created capable of playing this strategic role. These factors include factors related to input, process, output and the environment. The Wonogiri Vocational Training Center implements Competency-Based Training, where Competency-Based Training for trainees must be able to master 3 aspects of attitude, knowledge and skills.

Job competence is a specification of attitudes, knowledge and skills or expertise as well as their effective application in work in accordance with the required work standards. Competency certification is the process of granting competency certificates which are carried out systematically and objectively through a Competency Test which refers to the Work Competency Standards: both National, Special and International in nature. By having a competency certificate, a person will get evidence of written recognition of the work competence they have. Professional Certification can 
be carried out by LSP (Professional Certification Agency) which has been licensed by BNSP (National Professional Certification Agency).

Mathis Robert, (2002) which provides a definition of "Training is a process where people achieve certain abilities to help achieve organizational goals. Therefore, this process is tied to various organizational goals, training can be viewed narrowly or broadly". Rosidah (2003) which provides a definition of training is a short-term educational process using a systematic procedure of changing the behavior of employees in one direction in order to improve organizational goals.

Siswanto (2000) Comprehensive training includes the functions contained therein, namely planning, organizing, controlling and assessing general activities as well as skills training, as well as special education and training for employees. Andrew F.Sikula (2000) Training is a short term educational process utilizing systematic and organized procedure by which non managerial personel learn tecnical knoeledge ang skill for a definite pyrpose.

Benny A.Pribadi (2014) A training program can be said to be effective if it is able to make students or participants master the knowledge skills, skills, and attitudes required after completing the training program. Veithzal Rivai (2004) Factors that support the effectiveness of training include: 1 . Training material or content; 2 . Training methods; 3 . Trainer (instructor / trainer); 4. Training participants; 5 . Training facilities; 6 . Training evaluation.

Hung, Ratnata, Soysouvanh, \& Jiping (2013) Improving the quality of the workforce is carried out by holding job training aimed at improving and developing competence, productivity, discipline, attitudes and work ethic at a certain level so that skills and qualifications are in accordance with the level of position or occupation. The Association of ASEAN countries emphasizes regional cooperation on security, socio-culture and economic integration starting with the ASEAN Economic Community (AEC) in 2015. The formation of AEC creates added value in the region such as a connected economic market through a consistent production base, free trade investment, transfer capital, the labor market based on the general principle and equality of all ASEAN member countries that are a community. From the employment side, there will be ten heterogeneous labor markets in which countries recognize each other's qualifications. Vocational training programs must be developed according to the demands of the job market and industry needs, so that the industry will benefit directly when using competent workers from the vocational training program.

If the graduates are of high quality, the industry will get immediate benefits, because at the beginning of recruitment, the industry does not need to spend more to provide industrial training. Therefore, it is appropriate for the industry to have a responsibility to care, care and be responsible together with vocational training institutions. Three countries have implemented training programs that are integrated with industry. First, Australia has implemented vocational education training reforms in the last decade, incl. (M Tessaring \& Wannan, 2014): 1. introduction of a 
competency-based approach to training; 2. implementation of the Australian Qualifications Framework; 3. development of the training market according to the needs of students and industry; 4. mechanisms for enhancing learning pathways; 5. apprenticeship training reform (new apprenticeship scheme); 6 . introduction of national frameworks for quality assurance and national recognition of training providers.

A second example, best practice can be found in the dual education vocational training system in Austria, which has many good features, with a structured apprenticeship program that integrates learning in schools and on-the-job training (Hoeckel, 2010). The third example, the dual system in Germany has made the country have a competitive advantage by successfully reducing the unemployment rate. In Germany there is no resident over 25 years of age who has not worked for more than 3 months (Hippach-Schneider, Krause, \& Woll, 2007). To support a dual system, the government has established vocational education (collaborating with industry in a CSR / industrial social responsibility program) for citizens who do not have the ability to continue to higher education (C Windarto \& Sukiyo, 2014). From the description above, the formulation of the problem is defined as follows: 1 . The need for a vocational training curriculum to match the demands of the labor market; 2. Differences in skill levels and qualifications in the curriculum of vocational training providers; 3. Non-standard apprenticeship model between training providers and industry to ensure graduate competency.

Kamil (2003) Training as a program concept that aims to increase one's knowledge and skills (target students), develops very rapidly and is modern. The development of training models (capacity building, empowering, training, etc.) is not only happening in businesses, but in certain professional institutions the trainer model develops rapidly in accordance with learning needs, learning processes, assessments, targets, and other challenges. Rosset (1987) The training model initially developed in the business world, especially through traditional apprenticeships, in a traditional apprenticeship learning activities are carried out by a learning citizen (target students) and a learning resource (tutor), then in subsequent developments educational interactions that occur not only through individuals will be but it occurs through groups of learning citizens (target students, training targets) who have the same needs and goals as one, two, or more trainers (learning resources, traners). One of the concepts why the training model was built is that it really depends on the conditions of the learning community, the target students, and the trainer / tutor. This is very reasonable because the needs and objectives of training can be achieved if citizens learn, tutors understand each other, respect, understand and teach one another. A training model is considered effective when it can be based on a curriculum, approaches and strategies that are in accordance with the learning needs of students and the problems that occur in the middle. For that we need special requirements in building an effective and efficient training model. These 
requirements include the learning needs of training participants (target students, learning citizens). This term in the world outside of school is known as TNA (Training Needs Assessment), SMA (Subject Matter Analysis) and ATD (Aproaches to training and development).

Kamil (2003) Training needs are closely related to learning needs, learning needs are defined as the ability gap between the abilities already owned and the abilities demanded, or required in the life of the target students (training participants). This ability relates to the ability of knowledge, attitudes, values, and behavior according to the aspects that are the context of attention. If we are talking in relation to the training participants (targets), the training participants' needs (targets) are closely related to the knowledge, skills and attitudes that apply in their lives or in the world of work.

Djaali (2008) explains that interest is the individual's acceptance of something in his environment or the relationship between oneself and something outside of that individual. Aiken (1994) defines interest as a preference for activities over other activities. Surya (2003) Interest can be interpreted as feeling happy or unhappy in dealing with an object. Winkel (2004) Said that interest is a rather settled tendency to feel attracted to certain fields and feel happy to be involved in that field. Soufia and Zuchdi (2004) interest is the driving force that causes someone to pay attention to other people, activities or other objects. Witherington (1999) states that interest is one's awareness of an object, a person, a problem or a particular situation that has to do with itself or is seen as something that is conscious. Sardirman (2014) a person's interest in an object will be more visible if the object is in accordance with the target and is related to the desires and needs of a person concerned.

Sukardi (2014) The success of vocational training can be measured by the absorption rate of graduates in the job market. If graduates have the ability according to the required job market, it can be said that the learning process of vocational institutions has direct students and is ready to enter the job market. To achieve this, vocational training providers, namely BLKs, always improve the quality of learning through curricula according to the demands of the job market.

Nordman \& Pasquier-Doumer (2012) The four types of training held at BLK will be successful according to the size of the training competency required by the industry. It does not only focus on formal training but also pays attention to informal learning processes that can approach formal training. Apprenticeship at a large company is another form of formal training. Wagner (2008) 1. Critical thinking and problem solving; 2. Collaborate across networks and lead by influence; 3 . Endurance and adaptability; 4. Initiative and entrepreneurship; 5. Effective verbal and written communication; 6. Access and analyze information; 7. Curiosity and imagination.

Stern (2003 Competent graduates must have good basic skills and general job skills. General skills consist of basic skills, thinking skills, and personal qualities. According to McAshan, (1989), 
competency-based learning can be defined as: "a learning program where the learning outcomes or competencies expected to be achieved by students, storage systems and indicators of achievement of learning outcomes are formulated in writing since planning begins". Widiarni, 2008) Competencies that must be mastered by students need to be clearly and specifically formulated. The intended formulation should be based on the principle of "relevance and consistency between competencies and the material being studied, the time available, and the activities and learning environment used". Hamalik (2005) Program elements according to include training participants, trainers (instructors), length of training, training materials, and training methods. Sihombing (2001) The curriculum is a set of plans and arrangements regarding plans and arrangements regarding the objectives, program content, learning materials and methods used as guidelines for implementing learning activities. In implementing certain programs, it will always be based on a curriculum reference, both existing and newly developed. This developed curriculum will always be updated every time something better is found than what already exists. Rashid (2010) also stated that the factors of the quality of training content, participant motivation, and learning styles also contribute to the achievement of an effective training for the organization. Haslinda (2009) the effectiveness of training is influenced by the quality of the trainer and the accuracy of the training methods.

\section{Method}

This research will be conducted using a quantitative approach. As explained (Azwar, 2010, p. 5) research using the Quantitative Approach, which is an approach that emphasizes the analysis of numerical data (numbers) processed by statistical methods. Basically, the quantitative approach is carried out in inferential research (in order to test the hypothesis) and relies the conclusion of the results on a probability of null hypothesis rejection. With the quantitative method, it will be obtained the significance of group differences or the significance of the relationship between the variables studied. In general, quantitative research is research on a large sample.

s explained by Sugiyono (2013), quantitative research methods can be interpreted as research methods based on the positivist philosophy, used to research on certain populations or samples, sampling techniques are generally carried out randomly, data collection uses research instruments, data analysis quantitative or statistical in nature with the aim of testing predetermined hypotheses..

The research method that will be used by the writer for this research is Correlational Quantitative research method. According to (Azwar, 2010, pp. 8-9) correlational research aims to investigate the extent to which variations in a variable are related to variations in one or more other variables, based on the correlation coefficient. From this research, it can be obtained information about the level of the relationship that occurs, not about whether or not one variable has an effect on another variable. 
Quantitative correlational research is research that is intended to determine whether there is a relationship between two or more variables (Arikunto.S., 2005). Research with a quantitative approach is a study using an approach whose data is numerical and processed using statistical methods.

The location of this research is the UPTD BLK of the Wonogiri Manpower Office and PT Top $n$ Top Wonogiri. The object of this research is the graduates of apparel garment program training participants at the UPTD BLK of the Wonogiri Manpower Office who work at the PT Top n Top Wonogiri garment company.The population in this study were 65 participants in the BLK training at the Wonogiri Manpower Office.

Sampling is only for estimation, so if the subject is less than 100 , then it is better to take all of them so that the research is a population study. According to Wallen in Singarimbun, Masri and Efendi (2015: 157) that if the population is more than 100, then at least 100 is taken, and if the population is less than 100 then all of them are taken. The sample in this study was a portion of the training participants at the BLK Disnaker Wonogiri Regency with a total of 100 respondents. The sampling technique used for the determination of the sample was the quota random sampling method. The Wonogiri District Vocational Training Center (BLK) contained 65 Apple Garment training participants, while 65 apparel garment training participants were taken as a sample.

Independent variables are variables that influence, namely: Training Methods (X1), Instructors / Trainers (X2), Training Materials (X3), Facilities and Infrastructure (X4) and Certificates (X5) as dummy variables; The dependent variable is the variable that is influenced, namely: The employability of training graduates (Y).

The data collection method is one aspect that plays a role in the smoothness and success of a study. In this research method data collection used is as follows: Observation is direct observation in the field to obtain information or data from research in the form of the subject or object concerned. This study uses a questionnaire, the list of questions is structured in the form of multiple choice questions and open questions. Judging from the type of data and analysis, this research includes total population research in the quantitative data category, using a Likert-based scale of measurement (Sugiyono, 2010: 14) using a scale of five, namely 1, 2, 3, 4 and 5.

\section{Result and Discussion}

This study involved 65 respondents or all populations were sampled because the population was less than 100, with a sampling error of $5 \%$. The characteristics of respondents observed in this study include: gender, age, latest education and type of certificate. The description of the characteristics of the respondents is presented as follows: 
Table 1. Characteristics of Respondents Based on Gender

\begin{tabular}{ccc}
\hline Gender & Frekuensi & Persentase (\%) \\
\hline Male & 3 & 5,00 \\
Female & 62 & 95,00 \\
amount & 65 & 100,00 \\
\hline
\end{tabular}

Table 1. shows that there were 3 male respondents (5.0\%) and 62 female respondents $(95.0 \%)$. It can be concluded that the majority of respondents who attended training at the BLK Disnaker Wonogiri Regency Vocational Apple Garments were female.

Age is an important aspect that can be used to determine the trend of age who participated in training at the BLK Disnaker, Wonogiri Regency Vocational Apple Garment The description of the characteristics of the respondents by age is presented in the table below:

Tabel 2. Characteristics of Respondents by Age

\begin{tabular}{ccc}
\hline Age & Frekuensi & Persentase (\%) \\
\hline$<20$ tahun & 1 & 1,5 \\
$20-25$ tahun & 18 & 27,7 \\
$26-30$ tahun & 19 & 29,2 \\
$>30$ tahun & 27 & 41,6 \\
amount & 65 & 100,00 \\
\hline
\end{tabular}

Table 2. shows that respondents aged less than 20 years are 1 person (1.5\%), respondents aged 20-25 years are 18 people (27.7\%), respondents aged $26-30$ years are 19 people $(29.2 \%)$ and those over 30 years old were 27 people or $41.6 \%$. So it can be concluded that the majority of respondents who attended training at the BLK Disnaker Wonogiri Regency Vocational Apple Garments were more than 30 years old.

Descriptions of respondent characteristics based on recent education are presented in the table below:

Tabel 3. Characteristics of Respondents Based on Latest Education

\begin{tabular}{ccc}
\hline Type of Education & Frekuensi & Persentase (\%) \\
\hline primary school & 9 & 14,0 \\
Junior high school & 12 & 18,0 \\
senior high school & 44 & 68,0 \\
Diploma & 0 & 0,0 \\
bachelor & 0 & 0,0 \\
amount & 65 & 100,00 \\
\hline
\end{tabular}

Table 3 shows that respondents with the latest education with the last education were SMA / SMK equivalent as many as 44 people (68.0\%), respondents with the latest education as junior high school or equivalent were 12 people or $18.0 \%$ and respondents with the latest education was junior high school and equivalent as many as 9 people (14.00\%). So it can be concluded that the 
majority of respondents who attended training at the BLK Disnaker Wonogiri Vocational Garment Apparel were respondents with the latest SMA / SMK education equivalent.

There are two types of BLK graduate certificates, namely: (1) certificates issued by BLKafter participating in training at the BLK, (2) certificates issued by the National Certification Institute (LSP) if the Competency Test is declared competent. The description of the characteristics of the respondents based on the type of certificate is presented in the table below :

Tabel 4. Characteristics of Respondents by Type of Certificate.

\begin{tabular}{ccc}
\hline Type of Certificate & Frekuensi & Persentase (\%) \\
\hline BLK & 39 & 60,0 \\
LSP & 26 & 40,0 \\
amount & 65 & 100,00 \\
\hline
\end{tabular}

Table 4 shows that respondents with the type of certificate with the LSP certificate were 26 people $(40.0 \%)$, and respondents with a BLK certificate were 39 people or $60.0 \%$. So it can be concluded that the majority of respondents who attended training at the BLK Disnaker, Wonogiri Regency Vocational Garment Apparel were respondents with the type of training certificate at the BLK.

Descriptions of respondent characteristics based on job title are presented in the table below:

Tabel 5.Characteristics of Respondents by Position

\begin{tabular}{ccc}
\hline Type of Position & Frekuensi & Persentase (\%) \\
\hline Helper operator & 65 & 100,0 \\
Assistant SPV & 0 & 0,0 \\
SPV & 0 & 0,0 \\
Chief SPV & 0 & 0,0 \\
Senior Chief & 0 & 0,0 \\
Manager & 0 & 0,0 \\
amount & 65 & 100,00 \\
\hline
\end{tabular}

Table 5 shows that the respondents who graduated from training participants at BLK with operator positions were 65 people (100). So it can be concluded that the majority of respondents who attended training at the BLK Disnaker Wonogiri Vocational Garment Apparel were respondents with operator positions.

Multiple Regression Analysis of the Effectiveness of Apparel Garment Program Training at UPTD BLK Wonogiri. After carrying out the classical assumption test, it turns out that the research data on the regression model has been known to be in the best, linear and unbiased estimation (BLUE) conditions as it is required that the data must be normally distorted so the estimation of the effectiveness of the Apparel Garment Program Training at UPTD BLK Wonogiri can be continued by using Multiple Regression Analysis whose results are as shown in Table 6 
Table 6. Summary of the Influence of the Apparel Garment Training Program at BLK Wonogiri.

\begin{tabular}{cccc}
\hline Variabel & Koefisien Regresi & t-count & $\begin{array}{c}\text { Probabilitas } \\
\text { Signifikansi }\end{array}$ \\
\hline $\mathrm{X}_{1}$ & 0,058 & 2,608 & 0,012 \\
$\mathrm{X}_{2}$ & $-0,038$ & $-1,470$ & 0,147 \\
$\mathrm{X}_{3}$ & $-0,072$ & $-2,142$ & 0,036 \\
$\mathrm{X}_{4}$ & 0,131 & 3,373 & 0,001 \\
$\mathrm{X}_{5}$ & 0,769 & 3,298 & 0,002 \\
Constant & 2,550 & 3,235 & 0,002 \\
$\mathrm{R}^{2}$ & $: 0,541$ & & \\
$\mathrm{~F}-$-count & $: 13,931$ & & \\
$\mathrm{DW}$ & $: 1,498$ & & \\
$\mathrm{~N}$ & $: 65$ & \\
$\sum_{*}^{*}$ Var. Independen Signifikan : 4 dari 5 variabel \\
\hline
\end{tabular}

X1: Training Methods, X2 : Instructor / Coach, X3 : Training materials, X4 : Facilities and infrastructure, X4 : Certificate, Y : Job Ability of Training Graduates, $\mu$ : Disturbing variable (error term). Ased on the results of the multiple regression analysis, a regression equation model can be drawn up as follows:

$$
\mathrm{Y}=2,550+0,058 \mathrm{X} 1-0,038 \mathrm{X} 2-0,072 \mathrm{X} 3+0,131 \mathrm{X} 4+0,769 \mathrm{X} 5+\mu
$$

From the above equation it can be explained that if there is no change in the values of $\mathrm{X} 1, \mathrm{X} 2$, $\mathrm{X} 3, \mathrm{X} 4$, and $\mathrm{X} 5$ or the change in the independent variable is zero, then $Y$ will still get 2,550 which is positive (constant value). The regression equation model that can be written from these results is as follows: a) The constant coefficient of 2.550 shows the positive influence of the independent variables (Training Methods, Instructors / Trainers, Training Materials, Facilities and Infrastructure, and Certificates (X5), b) he regression coefficient X_1 of 0.058 means that the Training Method (X_1) has a positive effect on the formation of the Work Ability of Training Graduates (Y), c) The regression coefficient X_2 of -0.038 means that Instructor / Training (X_2) has a negative effect on the formation of the Work Ability factor of Training Graduates (Y), d) The regression coefficient $X_{-} 3$ of -0.072 means that the training material $\left(X_{-} 3\right.$ ) has a negative effect on the workability of training graduates (Y). e) The regression coefficient X_4 of 0.131 means that the Facilities / Infrastructure (X_4) have a positive effect on the formation of the Work Ability of Training Graduates (Y), f) The regression coefficient X_5 of 0.769 means that the certificate (X_5) has a positive effect on the formation of the Work Ability of Training Graduates (Y).

The coefficient of determination is used to determine how much influence the effectiveness of the Apparel Garment Training Program at UPTD BLK Wonogiri. The value of the coefficient of determination for the independent variable of more than 2 (two) is used Adjusted R square, as follows: 
Tabel 7. Coefficient of Determination

\begin{tabular}{lrrrr}
\hline Model & $R$ & R Square & $\begin{array}{c}\text { Adjusted } R \\
\text { Square }\end{array}$ & $\begin{array}{r}\text { Std. Error of } \\
\text { the Estimate }\end{array}$ \\
\hline 1 &, $7366^{\mathrm{a}}$ &, 541 &, 503 &, 80906 \\
\hline \multicolumn{2}{l}{ a. Predictors: (Constant), $\mathrm{X}_{5}, \mathrm{X}_{4}, \mathrm{X}_{1}, \mathrm{X}_{3}, \mathrm{X}_{2}$} & \\
b. Dependent Variable: $\mathrm{Y}$
\end{tabular}

The results of the output using the SPSS 21 program, it can be seen that the coefficient of determination (R2) of the regression model as in Table 13 is 0.503 . This shows that the variation of the effectiveness of the Apparel Garment Training Program at UPTD BLK Wonogiri can be explained by the independent variables (variables of Training Methods, Instructors / Trainers, Training Materials, Facilities and Infrastructure, and Certificates) of $54.1 \%$ while the remaining $45.9 \%$ explained by other variables outside the regression model used or not examined in this study.

The $t$ test was carried out to determine the effect of each or partially from the independent variables (Training Methods, Instructors / Trainers, Training Materials, Facilities and Infrastructure, and Certificates) on the dependent variable (the Training Graduates Work Ability variable). By looking at table 12 it can be seen that the effect of each variable of Training Methods, Instructors / Trainers, Training Materials, Facilities and Infrastructure, and Certificates on the factors forming the Work Ability of Training Graduates has a positive direction and has a significant effect with a value of $<0.05$. a) The Effect of Training Methods on the Work Ability of Training Graduates The results of the partial test ( $\mathrm{t}$ test) between the Training Methods variable and the Training Graduates' Job Ability variable showed the t value of 2.608 with a regression coefficient of 0.058 and a significance probability value of 0.012 which was smaller than 0.05 .

This means that the training method used has a positive effect on the workability of training graduates. b) The Effect of Instructors / Trainers on the Work Ability of Training Graduates The results of the partial test ( $\mathrm{t}$ test) between the Instructor / Coach variable on the Training Graduates' Job Ability variable show the $t$ value of -1.470 with a regression coefficient of -0.038 and a significance probability value of 0.147 which is greater than 0.05 . This means that the Instructor / Trainer does not have a positive effect on the Work Ability of Training Graduates. c) The Effect of Training Materials on the Work Ability of Training Graduates The results of the partial test ( $\mathrm{t}$ test) between the Training Materials variable and the Graduates Work Ability variable show the $t$ value of -2.142 with a regression coefficient of -0.072 and a significance probability value of 0.036 which is smaller than 0.05 . This means that the training material provided has a positive effect on the work ability of graduates. d) The Influence of Facilities and Infrastructure on the Work Ability of Training Graduates The results of the partial test ( $t$ test) between the Facilities and Infrastructure variables 
on the Graduates Work Ability variable show the $t$ value of 3.373 with a regression coefficient of 0.131 and a significance probability value of 0.001 which is smaller than 0.05 . This means that the available facilities and infrastructure have a positive effect on the work ability of graduates. e) The Effect of Certificates on the Work Ability of Training Graduates The results of the partial test ( $t$ test) between the Certificate variable on the Graduate Work Ability variable show the t value of 3.298 with a regression coefficient of 0.769 and a significance probability value of 0.002 which is smaller than 0.05 . This means that the available certificates have a positive effect on the Work Ability of Graduates.

From the explanation above, it can be concluded that the variables of Training Methods (X1), Instructors / Trainers (X2), Training Materials (X3), Facilities and Infrastructure (X4), and Certificates (X5) have a partially positive influence on the Work Ability of Graduates. Training at UPTD BLK Wonogiri.

The F statistical test basically shows whether all the independent variables included in the model have a joint influence on the dependent variable. The results of the calculation of the F Test with SPSS 21 can be seen in the following table:

Table 8 Results of the Calculation of the F Test Value (Simultaneously) ANOVAb

\begin{tabular}{lrrrrr}
\hline Model & Sum of Squares & $d f$ & Mean Square & \multicolumn{1}{c}{$F$} & Sig. \\
\hline Regression & 45,595 & 5 & 9,119 & 13,931 &, $000^{\mathrm{b}}$ \\
Residual & 38,620 & 59 &, 655 & & \\
Total & 84,215 & 64 & & & \\
$\quad$ a. Dependent Variable: $\mathrm{Y}$ & & & & \\
$\quad$ b. Predictors: (Constant), $\mathrm{X}_{5}, \mathrm{X}_{3}, \mathrm{X}_{1}, \mathrm{X}_{4}, \mathrm{X}_{2}$ & & & & \\
\hline
\end{tabular}

Simultaneous or simultaneous regression analysis can be explained that the F-count value is 13.931 with a significance level close to zero (0.000). Given the significance probability value of the F-count is very small (far less than 0.05) the variable of Training Methods, Instructors / Trainers, Training Materials, Facilities and Infrastructure, and Certificates simultaneously or simultaneously are proven to significantly influence the effectiveness of Graduates' Job Ability. Apparel Garment Program Training at UPTD BLK Wonogiri. The regression model can be said to provide the best fit performance.

Based on the results of research in the field, the variables of Training Methods (X1), Instructors / Trainers (X2), Training Materials (X3), Facilities and Infrastructure (X4) and Certificates (X5) together have a positive effect on the factors of Graduates' Job Ability. Training as evidenced by the value of $\mathrm{F}$ count 13,931 with a significance (sig) of 0,000. From the test results above, it shows that the four variables are Training Method (X1), Instructor / Trainer (X2), Training Material (X3), Facilities and Infrastructure (X4) and certificates (X5) form the effectiveness of the Work Ability of Training Graduates at the UPTD BLK Wonogiri to become the basis for making 
decisions about the suitability of training programs at BLK Wonogiri with what the Garment Industry needs. The following is an explanation of each hypothesis testing :

The results of the partial test ( $\mathrm{t}$ test) between the Training Method variables on the Work Ability variable of the Wonogiri BLK Training Graduates showed the $t$ value of 2.608 with a regression coefficient of 0.058 and a significance probability value of 0.012 which was greater than 0.05. This means that the Training Method has a positive effect on the Work Ability of Training Graduates at UPTD BLK Wonogiri. This means that the first hypothesis is accepted.

Based on the results of the study, it shows that the Training Method (X1) which consists of a statement of the accuracy of the characteristics of the participants, understanding and support and success can affect the effectiveness of training on work ability. This can happen because participants choose training based on the suitability of the participant's characteristics, abilities and support for success in the work desired by the trainees.

Theoretically, the method used in a training plays an important role in the process of transferring learning to the participants. (Kaswan, 2011) states that in order to choose a training method, instructors must adapt to the needs of the organization and characteristics of participants with the following objectives: (1) Motivating training participants to improve their performance, (2) Clearly describing the expected skills, (3) Giving training participants the opportunity to participate actively, (4) Providing opportunities / time to practice, (5) Provide time feedback on the performance of trainees, (6) Provide suggestions for strengthening when the trainees learn, (7) Structured from simple to complex tasks, (8) Can be adapted to specific problems, (9) Encourage positive transfer from training to work.

The results of the partial test ( $t$ test) between the Instructor / Trainer variables on the Work Ability variable of Training Graduates at UPTD BLK Wonogiri showed that the $t$ value was 1.470 with a regression coefficient of -0.038 and a significance probability value of 0.147 which was greater than 0.05 , with thus the second hypothesis is rejected. This means that the Instructor / Trainer does not have a positive effect on the Work Ability of the Wonogiri BLK Training Graduates. This means that the Instructor / Trainer does not make a significant contribution to the Work Ability of the Wonogiri BLK Training Graduates. This means that there is a good explanation and presentation of material, insight from a broad instructor, the ability of a good instructor to provide solutions, provide reinforcement to participants and always provide motivation to training participants, have not become one of the factors shaping the work ability of training graduates Wonogiri BLK.

From the above results it is contrary to the prioritized study which explains that in the implementation of the training program, the role of the trainer dominates in the delivery of training material. To support the smoothness and success of the training program, a well-classified trainer 
is needed. The main criteria needed by a trainer according to (Atmodiwirio, 2005) are: (a) Mastering the material being taught, (b) Skilled in teaching systematically, effectively, and efficiently, (c) Able to use methods and media that are relevant to general instructional goals and the specific instructional objectives of the subject.

The reality in the field that supports the insignificance of the instructor on the ability of the training participants is the job specification factor of the training participants when training at BLK is trained by instructors without the target time to complete the work, while the current condition after becoming employees they are at the target time. So that the training program based on the training material provided there is often no similarity in perceptions between the instructor and the trainee. This finding is supported by the theory presented by Simamora (1997) that the selection for a training program must explicitly take into account the participants' ability to master the training material and apply it later. As said (Simamora 1997) that, providing training to individuals with limited performance potential or no interest are simply a waste of time, money, and effort.

The results of the partial test ( $\mathrm{t}$ test) between the training material variables and the workability variable of the Wonogiri BLK Training Graduates showed a calculated value of -2.142 with a regression coefficient of -0.072 and a significance probability value of 0.036 which is smaller than 0.05 . This means that the training material has a positive effect on the Work Ability of Training Graduates at UPTD BLK Wonogiri, thus the third hypothesis is accepted.

This is due to the suitability of the material provided and in its implementation always paying attention to $\mathrm{K} 3$ procedures, therefore the training material is one of the factors shaping the existence of the Work Ability of Training Graduates at UPTD BLK Wonogiri. In accordance with what was stated (Hasibuan, 2005: 70) To improve the quality of learning, training material indicators can be seen from several indicators below a) The learning curriculum is tailored to the needs of the world of work, (b) The relevance of the learning content to the training topic being implemented, (c) The effectiveness of the target that becomes the benchmark for the achievement of a training program, (d) Building the integrity of the trainees in building group integrity so that post-training communication is established.

The results of the partial test ( $t$ test) between the Facilities and Infrastructure variables on the Work Ability variable of the Wonogiri BLK Training Graduates showed the t value of 3.373 with a regression coefficient of 0.131 and a significance probability value of 0.001 which is smaller than 0.05 . This means that the facilities and infrastructure have a positive effect on the Work Ability of Training Graduates at UPTD BLK Wonogiri, thus the fourth hypothesis is accepted.

This means that the facilities and infrastructure have a positive effect on the Work Ability of Training Graduates at UPTD BLK Wonogiri. This is because the available training facilities 
support the required learning process such as projectors, OHPs, laptops, printers and machines that are used in accordance with those in the company today, therefore the facilities and infrastructure are one of the factors forming the ability to work for training graduates. at UPTD BLK Wonogiri. As stated by Mulyasa (2013: 51) the use of infrastructure has a very important meaning, in addition to completing, maintaining, and enriching learning, learning resources can also increase learning activity and creativity which is very beneficial for both the trainer and the training participants. Utilization of facilities and infrastructure maximally allows training participants to explore various concepts in accordance with the subject being studied so as to add insight and understanding that is always actual and able to follow various changes that occur in society environment so that the facilities and infrastructure affect the ability of training participants at BLK graduates.

The results of the partial test ( $\mathrm{t}$ test) between the Certificate variable on the Work Ability variable of the Wonogiri BLK Training Graduates showed the $t$ value of 3.298 with a regression coefficient of 0.769 and a significance probability value of 0.002 which was smaller than 0.05 . This means that the certificate has a positive effect on the Work Ability of Training Graduates at UPTD BLK Wonogiri. Thus the fifth hypothesis is accepted.

This means that the certificate has a positive effect on the Work Ability of Training Graduates at UPTD BLK Wonogiri. This is because the certificate is a manifestation of the results of the Apparel Garment Program Training at UPTD BLK Wonogiri, therefore the certificate is one of the factors shaping the workability of the Training Graduates at UPTD BLK Wonogiri. Meanwhile, according to Mawanda, Akbar Hiznu (2018) human resource competency certification should create a positive aura in the implementation of competency certification in Indonesia so that Indonesian human resources are more competitive and ready to compete in a free market. Therefore, the importance of this competency certificate position, it is clear that a smart breakthrough is needed so that the implementation of competency certification can run quickly, affordably, but quality is maintained.

From the results of the research conducted, it was found that the Training Method (X1), Instructor / Trainer (X2), Training Materials (X3) and Facilities and Infrastructure (X4), and certificates (X5) together had a positive effect on the formation factors. Work Ability of Training Graduates at UPTD BLK Wonogiri. Overall, the results of this study support the theory that the four variables, namely Training Methods (X1), Instructors / Trainers (X2), Training Materials (X3) and Facilities and Infrastructure (X4), and certificates (X5) are factors for the formation of effectiveness. Apparel Garment Training Program at UPTD BLK Wonogiri, thus the sixth hypothesis was accepted.

In accordance with what was reported by Veithzal Rivai (2004: 240) the factors that support the effectiveness of training include training material or content, training methods, trainers (instructors / trainers), training participants, training facilities, training evaluation. 
From the characteristics of the respondents, it can be seen that the positions of training participants at BLKs, both those who have competency certificates and those who are not still at the operator level. This is because PT Top N Top is a garment industry which is a labor-intensive industry and the company has its own competency standards, thus the seventh hypothesis is rejected. The garment industry has not yet seen the type of certificate owned by their employees as having their own competency standards that have been determined by the company.

\section{Conclusion}

Based on the results of the analysis and discussion that have been stated in the previous chapter, the following conclusions can be drawn :

1. Competence has a significant effect on the work readiness of vocational students in West Lombok Regency. The results of research using SPSS 21 can be seen in the significance section, that the significance value is $0.019>0.05$. The results of the study showed that Ha was accepted and Ho was rejected. The hypothesis reads that there is a significant influence between competence on work readiness of vocational students.

2. Independence significantly influences work readiness. The results of the above study indicate that the significance value obtained by 0.001 , indicates that the significant value is less than 0.05. So it can be concluded that Ha was accepted and Ho was rejected. The hypothesis reads that there is a significant influence between independence on work readiness of vocational students in West Lombok Regency.

3. There is a significant influence between interest in work readiness of vocational students. The results showed that the significance value of $0.004<0.05$. The calculation results show that Ha was accepted and Ho was rejected. The hypothesis reads that there is a significant influence between interest in the work readiness of vocational students in West Lombok Regency.

4. There is a significant influence between discipline on work readiness of vocational students. The results of the study can be seen in the significance value, the significance value in this study was $0.005<0.05$. Based on the explanation above it can be interpreted that Ha was accepted and Ho was rejected. The hypothesis reads that there is a significant influence between discipline on work readiness of vocational students in West Lombok Regency.

5. Competence, independence, interest and discipline together have a very significant influence on the work readiness of vocational students in West Lombok Regency. The result of the research is that the significance value is simultaneously $0.000<0.05$ then Ha is accepted and Ho is rejected. The hypothesis jointly can be concluded that the competency variables $\left(\mathrm{X}_{1}\right)$, independence $\left(\mathrm{X}_{2}\right)$, interests $\left(\mathrm{X}_{3}\right)$, and discipline $\left(\mathrm{X}_{4}\right)$ together or simultaneously have an effect which is very significant to the work readiness (Y) of SMK students in the District West Lombok. 
The coefficient of determination in this study was $46.2 \%$, namely work readiness can be explained by four independent variables namely competence, independence, interest, and discipline. While the remaining $53.8 \%$ is explained by other variables not included in this study.

\section{References}

A. Fauzi, I. K. (2011). Mengelola Pelatihan Partisipatif. Bandung: Alfabeta.

Achmad, S. (2007). Budaya Organisasi Pengertian, Makna dan Aplikasinya Dalam Kehhidupan Organisasi. Yogyakarta: IBPP STIM YKPN.

Atmodiwirio, S. (2005). Manajemen Pelatihan. Jakarta: PT. Ardadiya Jaya.

Bartin, T. (2018). Strengthening the Role of Private Training Institutions for the Preparation of Skilled and Professional Workers. Advances in Social Science, Education and Humanities Research, 293.

Benny A.Pribadi, M. A. (2014). Desain dan pengembangan program pelatihan berbasis kompetensi implementasi model ADDIE (ertama ed.). Jakarta: Prenada Media Group.

BustilloT, E. V., Chang, M. C., \& Chen, D. (2011). Revitalisasi Balai Latihan Kerja di Indonesia:Tantangan dan masa depan. The Word Bank Office Jakarta..

Detty, R., dkk. (2009). Evaluasi Efektifitas Program Pelatihan. Journal of Management and Busines review, 6 .

Dobson, G. (2003). A Guide to WritingCompetency Based Training Materials. Commonwealth Australia: National Volunteer Skills Centre.

Finch, C. R. a. C. (1979). Curriculum development in vocational education. Boston: Allyn and Bacon Inc.

Garcia-Barbero, M. (1998). How To Develop Educational Programmes For Health Professionals. Copenhagen,: WHO Regional Office for Europe.

Gufran, Mukhadis, A., \& Putro, S. C. (2011). Pelaksanaan PLPG sebagai wahana pengembangan dan audit kompetensi dalam sertifikasi guru bidang kejuruan. Teknologi dan Kejuruan, 34(2), 115-128.

Hamalik. (2005). Kurikulum dan Pembelajaran. Jakarta: Bumi Aksara.

Hanafi, I. (2012). Re-orientasi ketrampilan kerja lulusan pendidikan kejuruan Jurnal Pendidikan Vokasi,, Vol 2.

Handoko, T. T. (2008). Manajemen Personalia dan Sumber Daya Manusia. Yogyakarta: Liberty.

Hippach-Schneider, U., Krause, M., \& Woll, C. (2007). Vocational Education and Training in Germany Training. . Luxembourg: European Centre for the Development of Vocational. 
Hoeckel, K. (2010). Learning for Jobs OECD reviews of vocational education and training. austria : Organization for Economic Co-Operation and Development (OECD.

Hung, H. X., Ratnata, I. W., Soysouvanh, B., \& Jiping, W. (2013). Cooperative, regional development and implementation of new curricula in vocational teacher education - experiences and reflections. TVET, 1-15.

Irwanto, W. S. (2012). Pengelolaan pelatihan ketenagakerjaan di Balai Besar Latihan Kerja Industri Surakarta. Kiat Bisnis, Vol 5.

Kamil, M. (2003). Model-Model Pelatihan. Bandung: Universitas Pendidikan Indonesia.

Kaswan. (2011). Pelatihan dan pengembangan untuk Meningkatkan Kinerja SDM. Bandung: CV ALfabeta.

Kirkpatrick, D. L. (1998). Evaluating Training Program, The Four Levels. San fracisco: BerrettKoehler.

M.Ihwanudin, A. B. N. R. P. (2017). The Efect of competency Based Training Program to Word Industry Demand at UPT-PK Singosari. IAdvances in Social Science, Education and Humanities Research, 116.

Mangkunegara. (2006). Evaluasi Kinerja Sumber Daya Manusia. Jakarta: Refika Aditama.

Masdarini, L., \& Devi, M. (2011). Pemahaman,sikap,dan unjuk kerja higiene sanitasi siswa dalam pengolahan dan penyajian makanan di SMK bidang keahlian tata boga. Teknologi dan Kejuruan, 34(2), 165-178. Sastrohadiwiryo, Siswanto. (2013). Indonesian Workforce Management. Administrative and Operational Approach. Jakarta: Earth Literacy.

Mathis Robert, J. J. (2002). Manajemen Sumber Daya Manusia. Jakarta: Salemba Empat.

McAshan, H. H. (1989). Competency-based education and behavioral objectives. New Jersey: Educational Technology Publications, Engelwood Cliffs. Oneil Jr.

Mulyadi, M. (2000). Efektifitas latihan kerja dalam hubungannya dengan pemanfaatan tenaga kerja lulusan Balai Latihan Kerja kabupaten Sleman Daerah Istimewa Yogyakarta. HUMANIORA(Vol 5, No 2: 2000).

Nordman, C. J., \& Pasquier-Doumer, L. (2012). Vocational education, on-the-job training and labour market integration of young workers in urban west Africa. Paris: UNESCO.

Normah Zakaria, M. H., Arasinah Kamis, Noor Azlin Yamin, Nur Nadiah Ismail. (2018). Efefective Competency-Based Training Learning Environment Toward Career Competencies Amongst Voational Students. Journal of Engineering Science and Technology, -(Special Issue on iCITE 2018), 18-26.

Palan, R. (2007). Teknis Mengimplementasikan Manajemen SDM Berbasis Kompetensi Untuk 
Meningkatkan Daya Saing Organisasi. Jakarta: PPM.

Rosidah, A. T. S. d. (2003). Manajemen Sumber Daya Manusia. Yogyakarta: Graha Ilmu.

Rosset, A. (1987). Training needs assesment. Educational Technology Publications englewood cliffs. New Jersey.

Sanjaya, W. (2011). Pembelajaran dalam Implementasi Kurikulum Berbasis Kompetensi. Jakarta: Kencana.

Sastradipoera, k. (2006). Pembangunan Sumber Daya Berbasis Pendidikan Kebudayaan. Bandung: Kappa Sigma.

Sihombing, D. (2001). . 2001. Tipografi Dalam Desain Grafis. Jakarta: Gramedia.

Simanjuntak. (2005). Manajemen Dan Evaluasi Kinerja. Jakarta: Fakultas Ekonomi UI.

Siswanto, B. (2000). Manajemen Tenaga Kerja. Bandung: Sinar Baru.

Sudira, P. (2011). Kurikulum dan pembelajaran pendidikan dan pelatihan vokasi menyongsong skill masa depan. Bali: Pengembangan Kurikulum Politeknik Negri Bali.

Sudiro.M.P, D. D. P. (2017). TVET Abad XXI Filosofi Teori, Konsep dan Strategi Pembelajaran Vokasional (Vol. 2). Yogyakarta: UNY Pres.

Sudjana, D. (2007). istem dan Manajemen Pelatihan : Teori dan Aplikasi. Bandung: Alfabeta.

Sukardi, T. (2012). Peranan bimbingan kejuruan terhadap pembentukan karakter kerja pada pembelajaran teknik pemesinan. Yogyakarta: Fakultas Teknik UNY.

Tessaring, M. (2009). Anticipation of skill requierements: european activities and approaches in international handbook of education forthe changing world of work, bridging academic and vocational learning.

Tessaring, M., \& Wannan. (2014). Vocational Education and Training - Key to The Future. Luxembourg: European Center for the Development of Vocational Training.

Tjiptoherijanto, P. (1996). Sumber Daya Manusia dalam Pembangunan Nasional. Jakarta: Lembaga Penerbit Fakultas Ekonomi Universitas Indonesia

UNESCO-UNEVOC. (2014). TVET formal, non-formal and informal systems. TVET.

Veithzal Rivai. (2004). Manajemen Sumber Daya Manusia Untuk. Perusahaan. Jakarta: PT. Raja GrafindoPersada.

Wagner, T. (2008). The global achievement gap. New York:: Basic Books.

Widiarni, D. R. (2008). Perencanaan Pembelajaran Berbasis kompetensi. Makalah Pada Mata Kuliah Perencanaan Pengajaran.

W indarto, C. Integrasi pelatihan vokasi dan pemagangan untuk memenuhi kebutuhan tenaga kerja yang kompeten Prosiding Seminar Nasional: Penguatan Hubungan antara Pengembangan 
Keterampilan, Pendidikan, dan Ketenagakerjaan Generasi Muda

Widoyoko. (2009). Evaluasi Program Pembelajaran. Yogyakarta: Pustaka Pelajar.

Windarto, C., \& Sukiyo. (2014). Curriculum Integration of Vocational Training and Apprenticeship Based Training to Fulfill Competent Workforce Market. 3rd International Conference on Vocational Education and Training ICVET 2014 Yogyakarta State University, 207 - 215. 